\title{
ATTEMPTS TO PASSAGE THE "VIRUS" OF NON-SPECIFIC URETHRITIS*
}

\author{
BY \\ R. R. WILLCOX, E. M. HOWARD, and the late G. M. FINDLAY \\ From St. Mary's Hospital, Paddington, and the Laboratories of the School of Pharmacy, London
}

During 1950-52 various methods were used in an attempt to find evidence for or against the theory that non-specific urethritis is due to a virus. A total of 234 skin tests for lymphogranuloma venereum (Willcox, 1954a), and psittacosis and catscratch fever (Willcox, 1954b), are reported below, with 412 complement-fixation tests for lymphogranuloma venereum (Macrae and Willcox, 1953) and 323 complement-fixation tests for enzootic abortion in ewes (Willcox and Stamp, 1954). The object of these studies was to determine whether patients with non-specific urethritis showed any cross-reactions when tested with antigens of the lymphogranuloma venereum-psittacosis-trachoma group of viruses. The findings, with the exception of some of the skin tests, which require confirmation, were negative.

A second approach to the problem was made by the examination of $1,463 \mathrm{Giemsa}$-stained specimens obtained from the urethra of patients with nonspecific urethritis, from their female consorts, and from controls, to assess the significance of various red and blue bodies seen in the specimens (Willcox, Howard, and Findlay, 1954). Although certain bodies were seen in a significant number of patients with non-specific urethritis and not in controls it was realized that the controls were persons with 'dry' urethrae. When recentlytreated gonorrhoea cases were used as controls the difference in incidence was no longer significant and it was concluded that the bodies seen were not concerned with the causation of non-specific urethritis.

The third approach, which forms the basis of this paper, was by means of inoculation of material into baboons, guinea-pigs, mice, and eggs.

(1) Baboons.-Inoculations of urethral material from three cases of non-specific urethritis, two of

*Received for publication May 18, 1953 which were complicated by Reiter's syndrome, were made on to the conjunctivae and into the knee-joints of three Papio hamadryas baboons (two males and one female). Material from the uncomplicated case was also inoculated intra-urethrally.

A few drops of a suspension of urethral scrapings in normal saline were instilled into the left eye, and $0.4 \mathrm{ml}$. of the same material was injected into the left knee-joint. Smears were taken from both eyes and from the knee-joint of one baboon immediately before inoculation with material from one of the two patients with Reiter's syndrome, and again at 7 and 14 days after inoculation ; they contained no bodies. The animal inoculated with material from the other case showing Reiter's syndrome contained no bodies before inoculation but some pus was present in both eyes 11 days afterwards. Giemsa-stained smears from the conjunctiva of the left eye showed a few granules, but the smear from the knee-joint showed no pathological changes. At 19 days, Giemsa-stained bodies were absent from all smears.

Material from the uncomplicated case of urethritis was inoculated into the left eye, left knee-joint, and urethra. Before inoculation nothing abnormal was detected in smears from any of these sites. One week after inoculation the smears were likewise free from Giemsa-stained bodies, although a little pus was noted in the right eye. Two weeks after inoculation, smears from all sources revealed no bodies.

Thus no conclusive evidence of transmission of the "virus" to the conjunctiva, knee-joint, or urethra of the baboon was obtained.

(2) Guinea-Pigs. $-0.2 \mathrm{ml}$. of a saline suspension of material obtained by scraping the urethra of a case of uncomplicated non-specific urethritis was injected into the right groins of two guinea-pigs. 
These were observed daily from 2 weeks but no glandular enlargement or other abnormality was noted.

\section{(3) Mice}

(a) Lungs.-Intranasal instillations of a saline suspension of urethral scrapings were given to young adult mice anaesthetized with ether. After 6 days the mice were killed and the lungs were inspected for segmental and pin-head-sized haemorrhagic lesions. Material for passage, if not used immediately, was kept in 50 per cent. glycerinephosphate at $-20^{\circ} \mathrm{C}$.

Some 245 different samples were injected into 1,488 mice during these experiments, and a further 247 mice used for other purposes in the laboratory were also examined.

144 samples, prepared from urethral scrapings of thirty patients suffering from non-specific urethritis, before, during, and after treatment with chloramphenicol, were instilled into the lungs of 870 mice. The donors comprised 21 patients with uncomplicated urethritis, four of their female consorts, and three cases of Reiter's syndrome, one with epididymitis and one with prostatitis.

The 64 ' RRW' control samples consisted of five specimens of normal saline, 21 specimens prepared from urethral scrapings from eleven patients without urethritis who were attending venereal diseases clinics, 28 specimens from seventeen apparently normal persons (students), eight specimens of nonurethral pus, and two specimens of cerebrospinal fluid. The 396 mice used in these experiments were anaesthetised at the time of instillation and again immediately before being killed. The 247 ' CMF' controls, on the other hand, were autopsied mice which had been used in the laboratory for other purposes. In addition, passage was attempted in 222 mice inoculated with material obtained from mice which had previously received material from 37 samples.

The lesions looked for were red haemorrhagic areas which might on occasion involve a whole lobe or a segment of the lung. Sometimes small circular pin-head-sized haemorrhages were seen and the incidence of these was noted. Three of these lung lesions which were sectioned appeared to consist of haemorrhages.

The results of these experiments are shown in Tables I and II, and the results in 396 control mice in Table III (opposite).

Although there was an incidence of 5.7-5.8 per cent. of lung lesions in the control mice, this figure was increased to 11.4 per cent. in the "urethritis" mice, and to 18.0 per cent. in the mice under passage, but it is not considered that lung lesions were related to the cause of non-specific urethritis. Early in the investigation it seemed as if some association was

TABLE I

INCIDENCE OF LUNG LESIONS IN MICE

Mice Inspected

\begin{tabular}{|c|c|c|c|c|c|c|c|c|c|c|}
\hline \multirow{3}{*}{\multicolumn{2}{|c|}{ Source of Material }} & & \multirow{3}{*}{$\begin{array}{c}\text { Mice } \\
\text { Injected }\end{array}$} & \multirow{3}{*}{ Survivors } & \multicolumn{6}{|c|}{ Lesions } \\
\hline & & & & & \multicolumn{2}{|c|}{ Large } & \multicolumn{2}{|c|}{ Pin-head } & \multicolumn{2}{|c|}{ Total } \\
\hline & & & & & No. & Percent. & No. & Percent. & No. & Percent. \\
\hline Urethritis $\ldots$ & . & .. & 870 & 793 & 40 & $5 \cdot 1$ & 50 & $6 \cdot 3$ & 90 & $11 \cdot 4$ \\
\hline Controls ' $\mathbf{R R}$ & '. & .. & 396 & 360 & 13 & $3 \cdot 6$ & 8 & $2 \cdot 2$ & 21 & $5 \cdot 8$ \\
\hline Controls ' $\mathrm{GM}$ & & .. & - & 247 & 0 & $\mathbf{0}$ & 14 & $5 \cdot 7$ & 14 & $5 \cdot 7$ \\
\hline Passage mice & .. & . & 222 & 212 & 26 & $12 \cdot 3$ & 12 & $5 \cdot 7$ & 38 & $18 \cdot 0$ \\
\hline Totals & $\ldots$ & $\ldots$ & 1,488 & 1,612 & 79 & 4.9 & 84 & $5 \cdot 2$ & 163 & $10 \cdot 1$ \\
\hline
\end{tabular}

TABLE II

INCIDENCE OF LUNG LESIONS IN MICE

Samples Tested

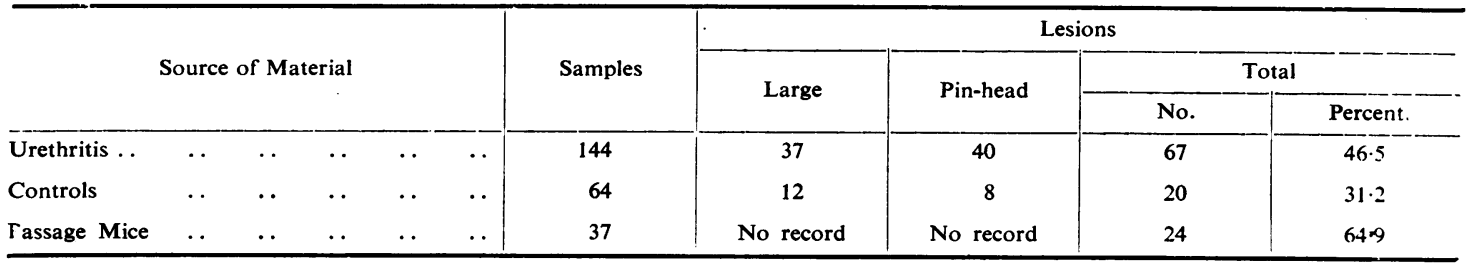


TABLE III

LUNG LESIONS IN CONTROL MICE

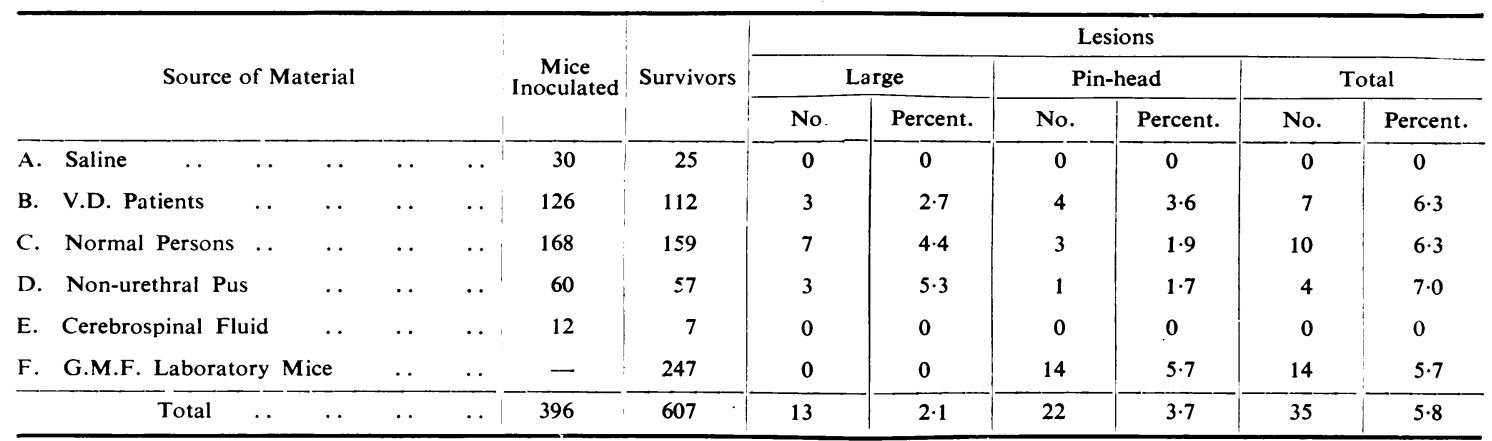

possible, but as the work progressed the picture changed.

If the lung lesions were related to the cause of non-specific urethritis, one would have expected a higher incidence of positive findings resulting from the first two samples of each case which were taken either both before, or one before and one during treatment with chloramphenicol, rather than from those taken after treatment. Table IV, however, shows no significant difference between the two groups.

The results have also been compared with those of the Giemsa-stained urethral scrapings (Table V). Although the terms 'positive' and 'negative' for Giemsa-stained bodies have been used, the conclusion has already been reached that the bodies seen were not the cause of non-specific urethritis (Willcox, Howard, and Findlay, 1954). In any event no significant relationship was noted.

Other Tables are available, but are not presented here, to show that the incidence of lung lesions in both the urethritis and control groups did not vary materially from month to month during the time when these tests were being conducted, nor according to the length of time that the samples were kept in the refrigerator before use.

(b) Brain. $-0.03 \mathrm{ml}$. of a 5 per cent. suspension of the previously described lung lesions from a

TABLE IV

MOUSE TESTS ON FIRST TWO SAMPLES COMPARED WITH REMAINDER

\begin{tabular}{|c|c|c|c|c|c|c|c|c|c|c|c|}
\hline \multirow{4}{*}{ Samples } & \multicolumn{8}{|c|}{ Mice } & \multicolumn{3}{|c|}{ Samples } \\
\hline & \multirow{3}{*}{$\begin{array}{c}\text { Mice } \\
\text { Injected }\end{array}$} & \multirow{3}{*}{$\begin{array}{c}\text { Sur- } \\
\text { vivors }\end{array}$} & \multicolumn{6}{|c|}{ Lesions } & \multirow{3}{*}{ Tested } & \multirow{2}{*}{ Lesions } & \multirow{2}{*}{ Present } \\
\hline & & & \multicolumn{2}{|c|}{ Large } & \multicolumn{2}{|c|}{ Pin-head } & \multicolumn{2}{|c|}{ Total } & & & \\
\hline & & & No. & Percent. & No. & Percent. & No. & $\begin{array}{l}\text { Percent. } \\
\text { Positive }\end{array}$ & & No. & Percent. \\
\hline First Two Samples. & 306 & 279 & 14 & $5 \cdot 0$ & 14 & $5 \cdot 0$ & 28 & $10 \cdot 0$ & 51 & 22 & $43 \cdot 1$ \\
\hline Remainder .. & 564 & 514 & 26 & $5 \cdot 1$ & 36 & $7 \cdot 0$ & 62 & $12 \cdot 1$ & 93 & 45 & $48 \cdot 4$ \\
\hline Totals .. & 870 & 793 & 40 & $5 \cdot 1$ & 50 & $6 \cdot 3$ & 90 & 11.4 & 144 & 67 & $46 \cdot 4$ \\
\hline
\end{tabular}

TABLE V

INCIDENCE OF LUNG LESIONS RELATED TO GIEMSA-STAINED URETHRAL SCRAPINGS

\begin{tabular}{|c|c|c|c|c|c|c|c|c|c|c|c|c|}
\hline \multirow{4}{*}{\multicolumn{2}{|c|}{$\begin{array}{c}\text { Giemsa-stained } \\
\text { Bodies }\end{array}$}} & \multicolumn{8}{|c|}{ Mice } & \multicolumn{3}{|c|}{ Samples } \\
\hline & & \multirow{3}{*}{$\begin{array}{c}\text { Mice } \\
\text { Injected }\end{array}$} & \multirow{3}{*}{$\underset{\text { vivors }}{\text { Sur- }}$} & \multicolumn{6}{|c|}{ Lesions } & \multirow{3}{*}{ Tested } & \multirow{3}{*}{ Lesions } & \multirow{2}{*}{ Present } \\
\hline & & & & \multicolumn{2}{|c|}{ Large } & \multicolumn{2}{|c|}{ Pin-head } & \multicolumn{2}{|c|}{ Total } & & & \\
\hline & & & & No. & Percent. & No. & Percent. & No. & Percent. & & & Percent. \\
\hline Positive (45). & $\ldots$ & 282 & 257 & 14 & $5 \cdot 4$ & 18 & $7 \cdot 0$ & 32 & $12 \cdot 4$ & 45 & 22 & $48 \cdot 8$ \\
\hline Negative (99) & .. & 588 & 536 & 26 & 4.9 & 32 & 5.9 & 58 & $10 \cdot 8$ & 99 & 45 & $45 \cdot 4$ \\
\hline Totals (144) & $\ldots$ & 870 & 793 & 40 & $5 \cdot 0$ & 50 & $6 \cdot 3$ & 90 & $11 \cdot 3$ & 144 & 67 & $46 \cdot 4$ \\
\hline
\end{tabular}


mouse receiving material from a case of non-specific urethritis, was injected into the brains of six mice. All six lived and the brains of two were sectioned one week later. The specimens showed perivascular "cuffing" and were photographed (Figure).
(4) Eggs.-A few experiments were undertaken at the laboratories of the School of Pharmacy before Dr. Findlay's death, and, through the courtesy of Prof. G. A. H. Buttle, these were afterwards continued by Miss E. M. Howard. Material relating to

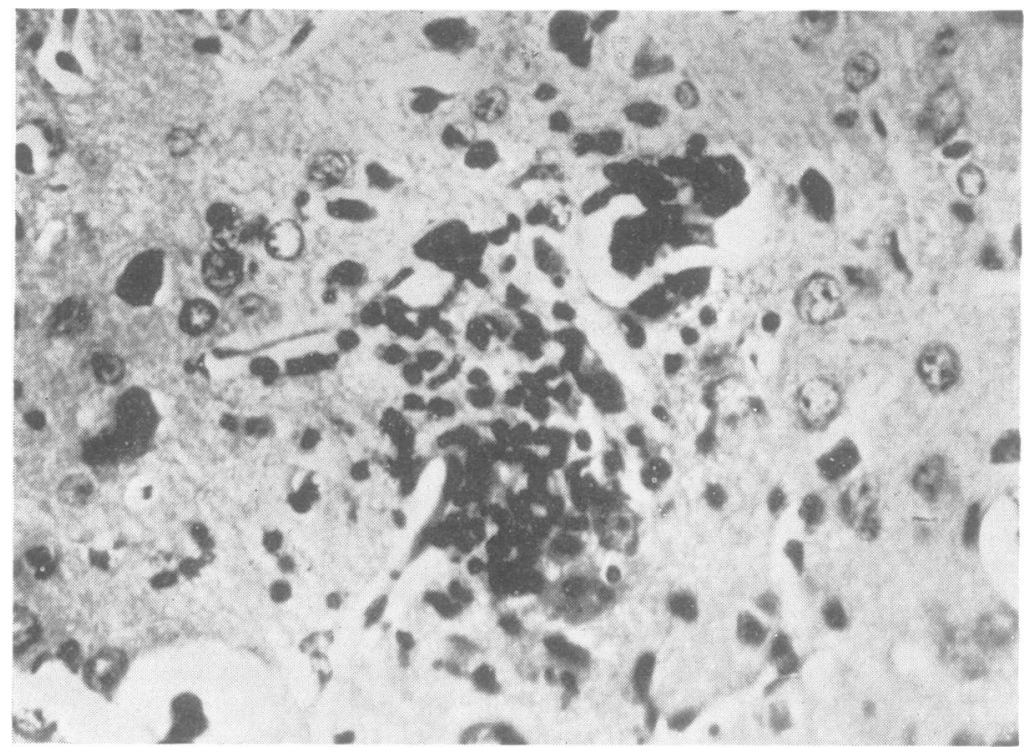

FIGURE.-Mouse-brain section after injection with $0.03 \mathrm{ml}$. of 5 per cent. suspension of lung lesions from a mouse which had received material from a case of non-specific urethritis.

A few drops of a 10 per cent. brain suspension from one of these mice were instilled intranasally into seven other mice, and the animals were killed after 7 days. All of the lungs showed some haemorrhages, and in two mice these were of considerable size.

Lung lesions from one of the control mice, which had previously had an intranasal inoculation with pus from an abscess of the neck, were ground, suspended, and inoculated intracerebrally into six mice. Two mice died and three were killed 19 days later. Brain sections showed a slight meningitis with a perivascular round cell infiltration, especially in the mid-brain. Polymorphonuclear leucocytes were not present.

In a further experiment urethral scrapings from a case of non-specific urethritis were injected intracerebrally into six mice. All of these mice lived and the brains of two were sectioned with negative findings. These brains were passaged intracerebrally also with a negative result.

Thus the significance of the abnormalities that were noted in these experiments depended upon the validity of the lung lesions, but these have already been shown to be unrelated to the cause of nonspecific urethritis. the virus of enzootic abortion in ewes, obtained from Dr. J. T. Stamp of Edinburgh, was first studied. About 100 8-day-old eggs were used and these were incubated for 5 days after inoculation. At first both yolk-sac and chorio-allantoic inoculations were practised, but the former were abandoned when it was noted that eggs so inoculated sometimes became contaminated despite the inclusion of penicillin in the inoculum. The investigation was continued with chorio-allantoic inoculations.

In the first pilot experiments some blue granules, and larger granular bodies staining blue with Giemsa, were noted in smears from the few eggs inoculated with material from cases of non-specific urethritis, but not in the controls. The experiments using urethritis material were repeated with six more eggs, and some blue "colonies," similar to those which had been noted in the urethral scrapings, were found in one of two surviving eggs. Passage was undertaken with unheated material and with material which had been heated at $56-60^{\circ} \mathrm{C}$. for $30 \mathrm{~min}$. as a control. The control eggs died, but similar blue bodies were found in each of the two eggs receiving unheated inoculum.

A third passage was attempted with six eggs 
which received unheated material, and four eggs which received heated material. One of two surviving eggs which had been given unheated inoculum showed blue intracellular granules, and two of the three survivors receiving heated inoculum showed nothing definite, although some questionable granules were noted in one.

A fourth passage with unheated material gave apparently positive results in four out of five surviving eggs.

Material from this case was then heated at $60^{\circ} \mathrm{C}$. for $30 \mathrm{~min}$. and inoculated into five eggs. Positive results were noted in two survivors, and also in one survivor receiving unheated material. The bodies seen were visible with both Giemsa and Castenada's stain (Bedson's adaptation).

In case the heating of the control material had been insufficient to kill the causal agent, material from the fourth and fifth passages was then pooled and divided into two parts, one of which was autoclaved for one hour. Both specimens were inoculated into eggs and four out of five survivors receiving heated material showed similar bodies, as did two out of two receiving unheated material.

More control eggs were then examined : four eggs were opened as for inoculation but were not inoculated, three others were inoculated with $0.2 \mathrm{ml}$. broth plus 200 units penicillin per $\mathrm{ml}$., and three were left untouched.

The eggs were incubated as before, but, when opened, all showed the bodies and granules originally seen.

\section{Summary}

In mouse-lung experiments, involving some 1,735 mice, no evidence was seen of the transmission of a cause of non-specific urethritis. The lesions studied had no relationship to the activity of the disease nor to the bodies seen in the Giemsa-stained urethral scrapings.
In inoculation experiments involving approximately 100 eggs no evidence of the transmission of non-specific urethritis was obtained.

The bodies and granules seen in the control eggs were similar to those observed in eggs inoculated with material from cases of non-specific urethritis. Moreover, the granules and granular bodies seen, both staining blue with Giemsa stain, bore a striking resemblance to those which had been noted in urethral scrapings from patients with non-specific urethritis.

These bodies have already been rejected as a possible cause of non-specific urethritis, and the present observations reinforce this rejection.

In experiments with baboons, guinea-pigs, and mouse-brain no positive results were obtained.

This work was conducted at the Laboratories of the School of Pharmacy, London, under the supervision of Dr. G. M. Findlay (technician Miss E. M. Howard) through the courtesy of Prof. G. A. H. Buttle.

Grateful acknowledgments are expressed to Prof. Buttle for kindly arranging for the completion of the work after Dr. Findlay's death in March, 1952.

This paper forms part of a Report submitted by one of us (RRW) to the British Medical Association at the end of his term of office as Insole Research Scholar 1951-52.

\section{REFERENCES}

- Macrae. A. D., and Willcox, R. R. (1953). British Journal of Venereal Diseases, 29, 231.

Willcox, R. R. (1954a). "Skin tests for lymphogranuloma venereum in non-specific urethritis" (in the press).

non-specific urethritis" (in the press).

- and Stamp, J. T. (1954). "The complement-fixation test for enzootic abortion in ewes in non-specific urethritis" (in the press).

_- Howard, E. M., and Findlay, G. M. (1954). “ "The significance of bodies seen in Giemsa-stained urethral scrapings in nonspecific urethritis", Amer. J. Syph., 38 (in the press). 